\title{
Electrochemical Determination of Activity of Acetylcholinesterase Immobilized on Magnetic Particles
}

\author{
Adam Kostelnik ${ }^{1}$, Alexander Cegan ${ }^{1}$, Miroslav Pohanka ${ }^{2,3 *}$ \\ ${ }^{1}$ Faculty of Chemical Technology, University of Pardubice, Studentska 95, Pardubice, Czech Republic \\ ${ }^{2}$ Faculty of Military Health Sciences, University of Defense, Trebesska 1575, Hradec Kralove, Czech \\ Republic \\ ${ }^{3}$ Department of Geology and Pedology, Mendel University in Brno, Czech Republic \\ E-mail: miroslav.pohanka@gmail.com
}

doi: $10.20964 / 2016.06 .39$

Received: 18 February 2016 / Accepted: 16 March 2016 / Published: 4 May 2016

\begin{abstract}
Acetylcholinesterase (AChE) is an enzyme which terminates action of neurotransmitter acetylcholine in cholinergic system. Activity of enzyme is commonly assayed by Ellman's method which has significant disadvantages like instability of reagents. Inability to use enzyme from the mixture repeatedly is another disadvantage. Therefore, we developed process using $\mathrm{N}$-(3-dimethylaminopropyl)-N'-ethylcarbodiimide hydrochloride (EDC) to immobilize AChE on the surface of magnetic particles, which enable to separate enzyme and use it repeatedly. To determinate activity of enzyme, we optimized square wave voltammetry (SWV) method where screen-printed sensor with Prussian blue (PB) modified working electrode was performed. We report limit of detection equal $8.1 \mu \mathrm{M}$ for a tested inhibitor of AChE tacrine. Comparing to the standard Ellman's test, the immobilized enzyme has limited sensitivity to interferences caused by organic solvents. The proposed method is readily to practical application.
\end{abstract}

Keywords: Acetylcholinesterase; tacrine; magnetic particles; screen-printed electrode; square wave voltammetry

\section{FULL TEXT}

(C) 2016 The Authors. Published by ESG (www.electrochemsci.org). This article is an open access article distributed under the terms and conditions of the Creative Commons Attribution license (http://creativecommons.org/licenses/by/4.0/). 